\begin{tabular}{|c|c|c|c|}
\hline Article Info & RESEARCH ARTICLE & ARAŞTIRMA MAKALESİ & \\
\hline Title of Article & \multicolumn{2}{|c|}{$\begin{array}{c}\text { Developmental Prospects of the Provincial } \\
\text { Cities by Branding } \\
\text { an Investigation over Sivas as a Sample }\end{array}$} & \\
\hline $\begin{array}{l}\text { Corresponding } \\
\text { Author }\end{array}$ & \multicolumn{2}{|c|}{$\begin{array}{l}\text { Feride Fatma BİLGİLI } \\
\text { İnönü Üniversitesi İktisadi ve İdari Bilimler Fakültesi, Siyaset Bilimi ve Kamu Yönetimi, } \\
\text { Kentleşme ve Çevre Sorunları, f.bilgili@ @otmail.com }\end{array}$} & \\
\hline $\begin{array}{l}\text { Received Date } \\
\text { Accepted Date }\end{array}$ & \multicolumn{2}{|l|}{$\begin{array}{l}11.12 .2020 \\
12.04 .2021\end{array}$} & \\
\hline Author / Authors & Dr. Feride Fatma BİLGİLi & ORCID: 0000-0002-5589-5126 & \\
\hline How to Cite & \multicolumn{2}{|c|}{$\begin{array}{l}\text { BILGIIL̇, Feride Fatma, (2021). Taşra Kentlerinin Markalaşarak Kalkınma Umudu - } \\
\text { Sivas Örneği Üzerinden Bir İnceleme, Kent Akademisi, Volume, 14, Issue 1, Pages: 214- } \\
229\end{array}$} & $\begin{array}{l}\text { Kent Akademisi } \\
\text { Urban Academy }\end{array}$ \\
\hline
\end{tabular}

\title{
Taşra Kentlerinin Markalaşarak Kalkınma Umudu Sivas Örneği Üzerinden Bir İnceleme
}

\section{Dr. Feride Fatma BíLGiLi}

\begin{abstract}
In the period following 1970, the neo-liberal transformation of the economy and the state has also caused various changes in the social, economic and spatial structures of urban centers. Capitalism in the world has come to such a final stage that major shifts in the paradigm were experienced in the economy, which have dramatically altered the structure of cities. Following the policies of deindustrialization, as the share of the industrial sector in urban economies decreased, the cities that could not receive sufficient public investments were forced to a situation in which they tried to realize their local development by "marketing their local originality". Originating from global capitalism, the competition-oriented development model imposed on cities has turned cities and regions into marketable products. Presently, not only products and services, but also cities have begun to be recognized as the subjects of marketing and therefore cities have become consumption materials or commodities. In the process called "urban branding" or "urban marketing", cities are looking for ways to gain advantage in the global economy by marketing their local originality in national and international markets, and to boost their spatial appeal by revealing their distinctive characteristics in order to attract the attention of tourists, investors and capital in return. The importance of the study is to emphasize that cities are trying to achieve their economic development through branding in the globalization process. In this study, based on the example of a provincial city of Sivas, the reflections of branding efforts on small cities will be examined. This research is a descriptive study in general survey type to evaluate the brand potential of Sivas city. The research evaluates the branding studies carried out in Sivas on an economic basis. The brand city potential of Sivas, the contribution of brand studies to the city economy and the brand city perception will be determined through field work and Evaluations and suggestions will be made in the light of the data obtained as a result of the study.
\end{abstract}

Keywords: Capitalism, City, Urban Marketing, Brand City, Local Development. 
ÖZ:

1970 sonrası dönemde ekonominin ve devletin neo-liberal dönüşümü, kentsel toplumsal, ekonomik ve mekânsal yapılarda da bir dönüşüme neden olmuştur. Sanayisizleşme politikaları sonrasında kent ekonomilerinde sanayi sektörünün payı azalırken yeterli kamu yatırımları alamayan kentler 'yerel özgünlüklerini pazarlama' yoluyla yerel kalkınmalarını gerçekleştirmeye çalışmak zorunda bırakılmışlardır. Küresel kapitalizmin kentler üzerinde yaratmış olduğu rekabet eksenli gelişme modeli kentleri ve bölgeleri de pazarlanabilen birer ürün haline getirmiştir. "Kentsel markalaşma/kentsel pazarlama" adı verilen bu süreçte kentler yerel özgünlüklerinin ulusal ve uluslararası piyasalarda pazarlanması yoluyla küresel ekonominin sağlayacağı avantajlardan yararlanabilmenin yolunu aramaya başlamışlardır. Çalışma, küreselleşme sürecinde kentlerin markalaşma yoluyla ekonomik kalkınmalarını gerçekleştirmeye çalıştıklarına vurgu yapmayı amaçlamaktadır. Bu çalışmada, bir taşra kenti Sivas örneğinden hareketle, markalaşma çalışmalarının küçük kentlere yansımaları irdelenecektir. Bu araştırma, Sivas kentinin marka potansiyelini değerlendirmeye yönelik genel tarama türünde betimsel bir çalışmadır. Araştırma, Sivas'ta yapılan markalaşma çalışmalarını ekonomik temelli olarak değerlendirmektedir. Saha çalışması yoluyla Sivas'ın marka kent potansiyeli, marka çalışmalarının kent ekonomisine katkısı ve marka kent algısı belirlenerek çalışma sonucunda elde edilen veriler ışığında değerlendirme ve önerilerde bulunulacaktır.

Anahtar Kelimeler: Kapitalizm, Kent, Kentsel Pazarlama, Marka Kent, Yerel Kalkınma.

\section{"Taşra Kentlerinin Markalaşarak Kalkınma Umudu Sivas Örneği Üzerinden Bir İnceleme"}

\section{GİRIŞ̧}

Var oluşundan bu yana kadar üretim biçimlerindeki dönüşümlerle birlikte kendileri de dönüşüme uğrayan kentler, günümüzde kapitalist üretim biçiminin etkisi altında önemli kırılma noktalarına uğramaktadırlar. Küreselleşen kapitalist kentler gün geçtikçe birbirine benzemektedirler. Kentler bu siradanlıktan kurtulmak ve daha çok yatırımcı ve turist çekebilmek amacıyla "markalaşarak" ön plana çıkmak istemektedirler. Bu süreç onları uluslararası pazarlarda pazarlanabilen birer tüketim nesnesi haline dönüştürmektedir. Kentlerin küresel ölçekte içinde yer aldığı yarış ve rekabet ortamı ekonomik ve kentsel gelişimlerine hız kazandırmak amacıyla çeşitli pazarlama stratejileri geliştirmelerine neden olmaktadır.

Özellikle 1970 sonrası yaşanan ekonomik ve politik yeniden yapılanma süreci kentleri de dramatik biçimde dönüştürerek küresel piyasalarda pazarlanabilen "metalar" haline getirmiştir. 1973'den bu yana yaşanan, yoğun kentler arsı rekabet ve kentsel girişimcilik döneminde seyirlik kentsel mekânların oluşturulması yoluyla kente imaj kazandırmak sermaye ve insan cezbetmek için bir araç haline gelmiştir (Harvey, 2010: 116). Artık dünyada ve Türkiye'de birçok kent, ekonomik kalkınmalarını gerçekleştirebilmek için “kentsel imaj"ın öneminin farkında olarak kentsel politikalarını belirlemektedirler. Bunun için kent imajı yeniden yapılandırılmaya çalışılarak şehirlerin küresel düzeyde temsil edilebilmesi amacıyla reklamcılık sektöründe kullanılan birtakım sloganlar ve söylemler, reklamlar veya logolar gibi geleneksel türdeki pazarlama araçlarını kullanmaktadırlar.

Marka çalışmalarında kent kimliğinin ve yerel özgünlüklerin markalaştırılarak kent ekonomisine katkı sunması amaçlanmaktadır. Başarılı markalaşma uygulamaları ile sermayeyi ve turistleri çekme stratejisi kentsel politikaların da belirleyicisi olmaya başlamıştır. Bu politikaları başarıyla uygulayabilen kentler, kentsel ekonomik hiyerarşide üst sıralarda yer almaktadır. Buna karşın kentsel kimlik oluşturma 
bakımından yeterli gelişme gösteremeyen ve markalaşma yarışında geri kalan kentlerin ise kalkınma sürecinde arkada kaldığ 1 görülmektedir.

Günümüzde kentler kapitalist kentleşmenin ortaya çıkardığı kentler arası eşitsizlikleri markalaşma yoluyla sermayeyi ve turizm potansiyelini kentlerine çekmeye çalışarak aşmaya çalışmaktadır. Kentler ekonomik gelir elde etme, istihdam olanakları yaratma, ödemeler dengesine katkı sağlama, döviz girdisi sağlama gibi yollarla kent ekonomisine katlı sağlamak istemektedirler. Marka kent çalışmaları, ilgi çekici mekânları bünyesinde barındıran kentlerin turizm ve yatırım gelirinin artışına paralel olarak ekonomik kalkınma süreçlerinin hız kazandığı söylenebilir (Okan, 2020: 104). Bu paralelde kapitalist kentleşme dinamiklerinin olumsuz etkilerini yaşamakta olan Sivas'ta da son dönemde markalaşma yoluyla ekonomik kalkınma yoluna gidilmektedir. Son dönemin kentsel politikaları kentin özgün varlıklarının ön plana çıkarılarak kente yatırım ve turist çekme stratejileri üzerine yoğunlaşmıştır. Çalışmadan elde edilen bulgular marka çalışmalarının kentte istihdama katkı sağladığı/sağlayacağı beklentisidir.

\section{REFAH DEVLETI VE SANAYİ ODAKLI KENT BİÇIMI}

II. Dünya Savaşının sonundan itibaren altın çağını yaşayan Keynesyen refah devleti uygulamaları, genel olarak dünya ülkelerinin birçoğunda ekonomik refahı beraberinde getirmişti. Gerçekten de, ekonomik büyüme o kadar hızlıydı ki savaş sonrası dönemin ilk otuz yılı 'altın çă̆' yılı gibi karakterize edildi (Hovard ve King, 2008: 206). Keynesyen iktisat teorisi ve ulusal kalkınma modeli çerçevesinde vücut bulmuş bir yeniden bölüşüm rejimi olan sosyal devlet, yarattı̆g 1 talep unsuruyla (geniş yığınların toplumsal üretimden aldıkları payın ve refah düzeylerinin artmasıyla) ulusal ekonomilerin büyümesini sağlamıştı (Özbek, 2007: 44). 1945-1975 arası dönem, refah devletinin fonksiyon ve kurumlarının genişlediği, gelirin devamlılığını sağlama ve yaşam standartlarını yükseltmenin temel ekonomik amaç haline geldiği yıllar olmuştur. Refah devleti, gelir kayıplarını telafi etme (işsizlik, hastalık, emeklilik), belirli harcamalar için doğrudan sorumluluk alma (sağl1k) ve çeşitli ödeneklerle sosyal adaleti sağlama gibi işlevleri yerine getirerek daha toplumsalcı bir devlet anlayışı getirmiştir (Rosanvallon, 2000: 57).

Keynesyen ekonomi politikalarının uygulandığı dönemlerde kentsel mekân, emeğin yeniden üretiminin mekânı olmuştur. Kalkınma iktisadının uygulandığı bu süreçte ketler, sanayi yatırımları çerçevesinde biçimlenmiştir. Devletin sanayi yatırımları ile kamu politikalarında öncü rolde olduğu bu dönemde kentsel yatırımlar kentlerin şekillenmesinde önemli rol oynamaktaydı. Keynesyen politikaların uygulandığı ülkelerde, hükumetler ekonomi politikalarının belirlenmesinde büyük ölçüde pay sahibi olmuşlardır. Bu dönemde devletler yalnızca piyasayı düzenlemekle kalmamış, bunun yanında doğrudan üretime de katk1 sağlamışlardır. Özellikle ekonomik gelişmenin kilit ve büyük yatırım gerektiren kesimlerinde devlet en önemli ekonomik aktörlerden biri haline gelmiştir (Ersoy, 2001: 39). Dolayısıyla, Fordizm döneminin yerel devleti, belirgin biçimde, Fordist kitlesel üretimi destekleyecek olan yerel altyapıyı sağlamış, kolektif tüketimi teşvik etmiş, yerel refah devleti politikalarını uygulamıştır (Jessop, 2005: 366).

Ancak 1960'lı yıllardan itibaren baş göstermeye başlayan ve 1973 ve 1979 yıllarında yaşanan Petrol Krizleriyle daha da derinleşen ekonomik krizler, refah devleti uygulamalarına karşı yöneltilen eleştirilerin artmasına neden olmuştur. Refah devleti problemlerin temel sorumlusu olarak ilan edilmiş ve kamu hizmetlerini de ülkelerin politik ve ekonomik gücü üzerinde yük olarak görülmüştür (Özdemir, 2007: 63). 1980'lere gelindiğinde ise Keynesyen iktisat politikasının ve ithal ikameci gelişme stratejilerinin terkedilmesi ve ardından neo-liberal ekonomik politikaların uygulanmaya başlamasıyla kent, değişimin odağı haline gelerek sermayenin yeniden üretiminin mekânı haline gelmiştir (Sert vd. 2005: 102). 


\section{NEOLİBERAL DÖNÜŞÜM SÜRECI VE SANAYİSIZZLEŞEN KENTLER}

1970’lerde azalan büyüme oranları, işsizlik dalgası, artan enflasyon ve kar oranlarının düşmesiyle yapısal bir krize giren dünya ekonomisi (Dumenil ve Levy, 2005: 9) krizden çıkış için neoliberal politikaları uygulamaya koymuştur. 'Neoliberalizm', serbest pazarları ve serbest ticareti vurgulayan bir ekonomik modelin dünya çapında yayılmasına adanmış ortak bir ideolojik ve politik ilkeler olarak tanımlanabilir (Steger, 2010: 10). Amerika Birleşik Devletleri'nde Ronald Reagan ve İngiltere'de Margaret Thatcher tarafindan uygulanmaya başlanan ve 'Reaganomics Thatcherism' olarak adlandırılan Neo-liberalizm, ve 21 yy. başlarında bir yüzyıl öncesi var olan serbestlik düzeyini gerçekleştirmiştir (Kazgan, 2000: 394). 1980 sonrası dönemde yaşanan ekonomik ve siyasal değişimler, temelinde serbest piyasa uygulamaları, özelleştirmeler, sanayisizleşme, sermayenin dünya çapında serbest dolaşımı olan neo-liberalizmin, giderek tüm dünyada hâkim paradigma haline gelmesine sebep olmuştur.

Bir önceki dönemde devletin aşırı büyümesini krizin nedeni olarak gören neo-liberal anlayış yeni dönemde devletin küçültülmesi esasını benimsemiştir. Neo-liberal dönemde devletin küçültülmesi uygulamalarının sonucu olarak özelleştirme ve sanayisizleşme politikaları ekonominin temel belirleyicileri durumuna gelmiştir. Devletin sanayi alanından çekilmesinin ekonomik ve toplumsal sonuçları olduğu kadar mekânsal sonuçları da oldukça önemli olmuştur. Sanayi yatırımlarından büyük ölçüde vazgeçilmesi, hem devlet sektöründe hem de özel sektörde sermayenin kentlere yönelmesini sağlamıştır (Şengül, 2009: 138).

Sanayi Devriminin ardından tarım sektörünün ekonomi içerisindeki göreli öneminin azalış1 gibi 1970 sonrası dönemde sanayinin ekonomideki göreli önemi azalırken, hizmetler sektörü ön plana çıkmaktadır. $\mathrm{Bu}$ türden sektörel değişmelerin kentler bazında oldukça önemli karşılıkları olmuştur. Tarım ve sanayi sektörlerinin istihdamdaki paylarının giderek azalıyor olması, kentsel mekânların pazarlanma stratejilerini de zamansal olarak değişime uğratmaktadır. Kalkınma iktisadının uygulandığı ve sanayii yatırımlarının artmış olduğu dönemde, kentsel mekânlar artan sanayi yatırımlarını kendilerine çekme gayretinde olmuşlardır. Sanayi yatırımlarını çekebilmek için çeşitli vergi ve teşvik kolaylıkları sağlamış ve bunun yanında yatırımlar için gerekli altyapı imkânları sunmaya çalışmışlardır. Daha sonraki yıllarda üretim biçimlerinde meydana gelen değişimlerle sanayi sektörünün önemini kaybetmesiyle, kentler sanayi dış1 sektörlere (özellikle hizmet sektörüne) yönelmişlerdir. Ortaya çıkan bu durumla beraber kentler, küresel dünyada var olabilmek için yeni pazarlama stratejileri geliştirmek zorunda kalmışlardır (Tek, 2009: 170).

Harvey'in sermayenin ilk çevrimden ikinci ve üçüncü çevrimlere aktarılması olarak yorumladığı bu durum; sermaye birikimi ilk çevrimdeki etkinliğini tamamen yitirmeden eş zamanlı olarak ikinci ve üçüncü çevrimlere aktarılıyor, yani endüstriyel üretim azalarak da olsa varlığını korurken ticaret, turizm, hizmetler gibi "tüketim-odaklı" sektörlere daha fazla yatırım yapılması sonucunda artık büyük ölçüde kentler ve tüketim faaliyetleri üzerinden işleyen bir ülke ekonomileri ortaya çıkmaktadır (Penpecioğlu, 2013: 65). Harvey (2010: 116), kapitalist dünyada kentlere esas olarak finans, mimari, tüketim ve eğlence merkezleri niteliğiyle birbirleriyle yarışmaktan başka bir olanak bırakmamacasına yaşanan sanayisizleşme ve yeniden yapılanmanın göz önünde tutulacak olursa, bu kentlerin neden bu kadar telaş içine düştüklerinin ve başarılı modelleri neden taklit ettiklerinin anlaşılacağını ileri sürmektedir.

\section{NEOLİBERALIZMİN KENTE BAKIŞI: METALAŞAN VE YARIŞ(TIRIL)AN KENTLER}

Toplumsal pratikleri metalaştırarak kendisini var eden kapitalizm, kent mekânını kendisi için en önemli meta haline getirmiştir. Kentlerin küresel hiyerarşik ortamda rekabet edebilmeleri için, belirli imgelerin üzerinden kentlerin markalaştııılması ve böylelikle kentsel gelişmenin sağlanarak kente yatırımcı ve turist çekilebilmesi temel kentsel politikalardan biri haline gelmiştir.

1980’lerin başından itibaren dünyada ortaya çıkan yeni politik ve ekonomik değişimler, önceki dönemin "emek gücünün kentleşmesi" olgusunu sönümlendirirken, artık "sermayenin" kentlerin biçimlenmesinde başat rol oynadığı dönemin yolunu açmıştır (Şengül, 2009: 138). Özellikle 1990’lı yılların başından 
itibaren, alışveriş merkezleri, beş yıldızlı oteller ve iş merkezleri kentlerin ufuklarını daha önce görülmemiş bir hızla işgal etmeye başlamış, ilk dönemden beri spekülatif karların aracı olan kent, stratejik bir meta olarak her zamankinden daha fazla merkezi bir konuma gelmiştir (Şengül, 2009: 141). Bahsedilen bu süreçte kentlerde sermayenin başat rol üstlenmesi, kentlerin sermayeyi çekebilmek için küresel ölçekte bir yarışa girmesine neden olmuştur.

Kentler süreç içerisinde neo-liberalizmin kendini yeniden ürettiği merkezler haline dönüşmüşlerdir ve bu nedenle sermayenin kendini yeniden ürettiği mekân ile neo-liberalizm arasında oldukça sıkı bir ilişkisellik bulunmaktadır. Neo-liberal kentleşme, neo-liberalizmin doğrudan kentsel mekana yoğunlaşmasıyla birlikte kentsel toprakların rant sağlayan bir metaya ve tüketim alanına dönüştürülmesini ifade etmektedir. Kapitalist üretim sisteminde kentsel mekân örgütlenirken değişim değeri kullanım değerinin önüne geçmektedir. Böylelikle mekân metalaşırken kapitalizm de kentin canlılığını ve farklılıklarını soyutlaştırmaktadır. Herhangi bir mekânın tarihsel değeri ancak mekân değişime konu olduğunda önemli olabilmektedir. Dolayısıyla kapitalizm kendi değerlerini empoze ederek somut mekânları tehdit etmekte ve birbirine benzer kılmaktadır (Şengül, 2001: 16). Kapitalist kentleşme süreçlerinin neden olduğu birbirine benzeşen kentler, bu durumdan kurtulmak için farklılıklarını ve özgünlüklerini ön plana çıkararak, kendilerini küresel piyasalarda pazarlamaya çalışmaktadırlar.

Küreselleşme olgusu günümüzde kentler üzerinde bir baskı unsuru yaratmakta ve kentleri küresel ölçekte rekabet etmeye zorlamaktadır. Bu baskı ve rekabet ortamında kentler farklılıklarını ortaya koymaya zorlanmaktadırlar. Kentler, küresel kapitalist rekabet ortamında diğer kentlerden öne geçebilmek, ekonomik avantajlardan yararlanabilmek; yerel kalkınmalarını gerçekleştirebilmek amacıyla mekânsal çekiciliklerini artırmaya çalışmaktadırlar. Kentler, var olan yerel özelliklerini ön plana çıkararak, küresel sermayeyi, uluslararası kurumları, nitelikli işgücünü ve turistleri çekebilecek bir imaj oluşturmaya çalışmaktadırlar. Kentlerin küresel rekabet ortamında rekabet gücü kazanabilmeleri açısından yerel kimliklerinin yeniden keşfedilmesi ve yerel potansiyellerinin kullanılması, kendilerine özgü ayırt edici göstergeler taşımaları bir gereklilik olarak görülmektedir (Özerk ve Yüksekli, 2011: 82).

Ancak şöyle de bir durum var ki, küresel ölçekteki bu yarışma gelişmişlik düzeyleri birbirinden çok farklı yerel birimlerin hepsinin aynı koşullar içinde yarışa katılmalarını öngörmektedir (Ersoy ve Şengül, 1998: 5). Diğer bir anlatımla, var olan eşitsiz yapı veri olarak alınmakta ve örneğin kişi başı GSYH's1 7.300 dolar olan Sivas ya da 3.400 dolar olan Ağrı ile 17.800 dolar olan İstanbul, aynı yarışın içine sokulmaktadır (TÜİK, 2019). "Eşit olmayan koşullarda” yarışa sokulan kentlerden ekonomik olarak geri olan kentler yarışta ön plana çıkabilmek için tarihi, doğal ve kültürel özelliklerini küresel ölçekte pazarlamaya çalışmaktadırlar. Kentler, markalaşmanın sağlayacağı avantajlardan yararlanarak, küresel ortamda pazarlanabilirliklerini artırmak amacı taşımaktadırlar. Bu amaç günümüzde kentlerin olduğu kadar ülkelerin, bölgelerin, yörelerin, köylerin ve hatta çok küçük merkezlerin de en önemli hedeflerinden biri haline gelmiştir (Zeren, 2011: 97).

\section{KENTIN YENI SÖYLEMI: KENTSEL MARKALAŞMA}

Marka en genel anlamıyla, arma, alâmetifarika, amblem, damga, simge, logo, patent gibi kavramlara karşılık gelmektedir. Ancak, marka onlardan daha fazladır ve onları da içinde barındırmaktadır. Marka, bir kurum veya kuruluşun kendine seçtiği, ticaret eşyası üzerine konulan, o eşyayı üreten veya satanı tanıtan resim, harf vb. özel işarettir. Markalaşma, bir ürünün, bir şeyin tanınma, isim yapma ve bilinme sürecidir. Markalaşma sürecinde tek bir hedef vardır: bilinmek. Bilinmek için firmalar reklamlarla ürünü piyasada tanıtmaya çalışırlar (Kaypak, 2013: 340). O halde marka ve markalaşma süreci, bir ürünü benzerlerinden ayıracak ve tercih edilmesini sağlayacak farklılıklar bütünüdür ve ürünün sunuluş biçimi markayı oluşturmaktadır. 
Buna göre kent markalaşması; "Ürün veya hizmetlere ait markalaşma stratejilerinin kent üzerinde tatbikiyle, kente ve kentliye dair her tür çıktıya değer katmak suretiyle insanların zihninde olumlu bir algı oluşumunun yolunu açmayı amaçlayan, mevcut ya da potansiyel misafirleri /müşterileri için çekim merkezi haline gelmek iddiasında olan kentler tarafından yapılan faaliyetlerin göstergesi" olarak tanımlanabilir (Zeren: 2011: 97).

Kentsel markalaşma, pazarlama tekniklerinin kentler üzerine aktarılarak kentlerin uluslararası piyasalarda pazarlama sürecidir. Marka, pazarlama disiplininin bir ürünüdür ve marka stratejisinin önde gelen isimlerinden Kotler vd. (1993) rekabetin yalnızca ürünler ve firmalar arasında değil, ülkeler ve şehirlerarasında da gerçekleştiğini ve mekânsal yapıların da birbirleri ile rekabet edebileceklerini belirtmektedir. Mekânsal yapılanmalar ve kentler de tıpkı ürün ve hizmetler gibi pazarlamaya konu olabilmekte ve "marka kent" olarak konumlandırılabilmektedirler (Tek, 2009: 170).

Günümüzde pazarlama mantığı üzerinden kentsel markalaşma iki ana yöntemle yapılmaktadır. Bunlardan birincisi "mega projeler" ya da "dev yatırımlar" üzerinden markalaşma çalışmalarıdır. "Rekabet eden kentler", "kentlere yatırım çekme”, "marka kentler", "kentsel pazarlama” gibi neo-liberal düşüncenin ürünü olan bu uygulamalar (Uğurlu, 2013: 7) kentlerde büyük çaplı mekânsal projeler, alışveriş merkezleri, iş-ticaret merkezleri, beş yıldızlı oteller yoluyla kentsel yaşamın kalitesini artırma ve yeni istihdam olanakları sunmanın yollarını aramaktadırlar. Kentsel mekânda küreselleşme ile birlikte meydana gelen tüketim eksenli yaklaşımlar, kentlerin fiziksel mekânını da dönüştürmektedir. Ticaret ve finans merkezleri, alış veriş merkezleri ve yüksek katlı konutlar gibi yapılar inşa edilmektedir (Penpecioğlu, 2013: 100).

Kentsel markalaşmayı gerçekleştirmenin diğer önemli bir yolu da kültür odaklı gelişim stratejileridir. Kültür odaklı gelişim stratejileri, kültürel turizm sektöründe istihdam oluşturma, kentlerin turistik altyapı olanaklarının artırılmasını sağlama ve kentlerin küresel arenadaki ulusal ve uluslararası önemini artırma gibi amaçlar taşımaktadır (Dündar, 2010: 57). Türk kentlerinin de içinde bulunduğu bir çok dünya kenti Expo Dünya Fuarları, kültür başkentliği, festivaller, bianeller, olimpiyatlar gibi mega etkinlikler düzenlemek yoluyla kentsel marka oluşturma çabasıyla küresel yarışa dahil olmaktadırlar (Özerk ve Yüksekli, 2011: 87).

Son olarak şunu da belirtmek gerekir ki kentsel markalaşma, yerel birimlerin farklı ve güçlü özelliklerini açığa çıkaran, kenti bir kültürel obje olarak ele alan ve kentlere değer katan bir unsur olmakla beraber kentlerin markalaştırılması için yapılan faaliyetler, kentlerin yerel kimlik öğelerini metalaştırarak onları birer "ürün"e ve "tüketim nesnesi"ne dönüştürmektedir.

\section{TAŞRA KENTLERİNDE MARKALAŞMA ÇALIŞMALARI}

Dünya ülkelerinde ve Türkiye'deki metropol kentlerde olduğu gibi taşra kentlerinde de markalaşma eğilimleri gün geçtikçe artan bir ivme kazanmaktadır. Küreselleşme ve sermaye hareketliliği konusunda izlenecek stratejileri belirleyen birçok kent yönetimi günümüzde özel şirket mantığında hareket eden girişimci kent (entrepreneurialism) politikaları izlemektedir. "Küresel Kent", "Dünya Kenti”, "Rekabetçi Kent" gibi kavramları besleyen kentler arası rekabet politikaları günümüzde büyük kentlerde olduğu gibi taşra kentlerinde de "Marka Kent" stratejileri ile sürdürülmektedir (İnce ve Dinçer, 2017: 636). Taşra kentleri de büyük kentlerle aynı yarışın içine sokulmakta ve küresel ölçekte bir hiyerarşinin içine girmeye zorlanmaktadirlar.

Kent markalamada birincil amaç, kente yönelik bir kimlik ve bir imaj yaratımı çabasıdır. Markalaşan kentler doğal olarak diğer kentlerle arasında belirgin farklılıklarını ortaya koyacaklardır (Görgülü, 2020: 716) başlamıştır. Nitekim rakiplerinden ayrışmak, kendi özgünlüklerini ortaya çıkarmak ve küresel pazarlarda yer bulmak isteyen kentler, markalaşma ihtiyacı ile marka kent olma hedefine odaklanmıştır (Çalapkulu ve Kızıldağ, 2021: 711). Bu strateji üzerinden belirlenen kentsel politikalar küresel kentlerin 
tipik özelliği durumuna gelmiştir. Günümüz kentleri sermaye ve turist çekme noktasında birbirleriyle rekabet ederek kentler arası yarışta öne geçmeye çalışmaktadır.

Küresel kentler hiyerarşisi açısından dünyanın önde gelen marka kentleri New York, Londra ve Tokyo ve Paris gibi simge kentlerdir. Kapitalist kentleşme süreçlerinde artık dengeler değişmiş, bazı kentler tanınma açısından ülkelerinin önüne geçmiş durumdadırlar; güçlerini ülkelerinden değil, kendilerinden aldıkları bir aşamaya geçmişlerdir (Kaypak, 2013: 344). Daha önce de değinildiği gibi devlet anlayışında yaşanan paradigma dönüşümü sonrasında ortaya çıkan sanayisizleşme sürecinde yeteri kadar kamu yatırımı alamayan kentler özel sermayeyi çekme yarışına girişmişlerdir. Ne var ki, bu süreçte büyük kentler ile küçük ölçekli kentler aynı yarışın içinde yer almaktadırlar. Artık taşra kentleri de tıpkı büyük kentlerde olduğu gibi sermayeyi, yatırımcıyı ve turistleri çekebilmek için markalaşmaya çalışmaktadırlar.

Bu amaçla Türkiye'de 2006 yılında Kültür ve Turizm Bakanlığı tarafından hazırlanan "Türkiye Turizm Stratejisi 2023 Eylem Planında" 2023 yılına kadar Ankara, İstanbul, İzmir ve Antalya'da şehir turizmini geliştirmeye yönelik plan ve projeleri yaşama geçirileceği; Adıyaman, Amasya, Bursa, Edirne, Gaziantep, Hatay, Konya, Kütahya, Manisa, Nevşehir, Kars, Mardin, Sivas, Şanlıurfa ve Trabzon illerinde ise kültür turizmi canlandırılarak marka kültür kentleri oluşturulacağı ifadelerine yer verilmektedir. Planda ülkemizin doğal, kültürel, tarihi, turizmine önem verileceği ve marka kentlerin oluşturulmasına çalışılacağı ifade edilmektedir. Ayıca "Zengin kültürel ve doğal değerlere sahip kentlerimizin markalaştırılarak, turistler için bir çekim noktası haline getirilmesi" stratejisine yer verilmiştir (Türkiye Turizm Stratejisi 2023 Eylem Plan1).

\section{SIVAS'IN MARKALAŞMA SÜRECI}

Bu bölümde Sivas'ta kent ekonomisine katkı sunacak mevcut markalaşma potansiyeli ve Kentin markalaşma süreci ele alınacaktır.

\subsection{Sivas Ekonomisinin Mevcut Durumu ve Markalaşmanın Kent Ekonomisi Açısından Önemi}

Tarihi M.Ö 3000'lere dayanan bu kadim şehir tarihi boyunca Hititliler, Frigyalılar, Selçuklular ve Osmanlılar gibi pek çok medeniyete ev sahipliği yapmıştır. Özellikle Selçuklular ve Osmanlılar döneminde siyasi ve ticari yönden stratejik bir öneme sahip olmuştur. Cumhuriyet döneminde oldukça etkin rol oynayan Sivas günümüzde İç Anadolu'nun küçük ölçekli olarak adlandırabileceğimiz bir taşra kenti olma özelliğine sahiptir. Sivas nüfusu 2020 yılına göre 635.889'dir (tüik.gov.tr). Özellikle 1970 sonrası dönemde ekonomik nedenlerle büyük şehirlere göç vermektedir. Kentte net göç hızı -8.45 'dir. İşsizlik ve istihdam olanaklarının yetersizliği göç sürecini hızlandıran ana etkenler olarak kabul edilmektedir. İşsizlik oranı \%14.5 ile Türkiye ortalamalarının üzerindedir.

İlin genel genel olarak ekonomisi tarım ve hayvancılığa dayanmaktadır ve bu oran il genelinde 66,5 dolayındadır. Sanayi sektörünün payı 5,4, hizmetler sektörü ise 28,1'dir (Oran, 2014-2023 Mevcut Durum Analizi). Sivas ili kültürel mirası, yeraltı ve yerüstü zenginlikleri, tarımsal üretim gücü ve ulaşımı ile zengin bir potansiyele sahiptir. Madenlere ve yerüstü zenginliklerine sahip olmasına rağmen sanayi potansiyel düzeyinin altında kalmaktadır. İl ekonomisi genel olarak tarım, ticaret, haberleşme ve sanayi sektörlerine dayalıdır. Sanayi sektöründe imalat sanayi değil madencilik ve enerji alt sektörlerinin sanayi sektörü içerisindeki ağırlığıyla ilişkilidir. İmalat sanayinin ne yazık ki sermayeden yeterince pay alamadığ 1 dikkat çeken önemli bir husus olmaktadır.

Sivas sahip olduğu tarihi, kültürel ve doğal zenginlikleriyle iyi bir marka kent olabilme potansiyeline sahip bir şehirdir. Bu yönüyle oldukça zengin tarihi ve kültürel mirasa sahiptir. Bunun haricinde sahip olduğu doğal güzellikleri, endemik bitki ve hayvan türleri, yeraltı ve yer üstü zenginlik kaynaklarıyla oldukça geniş bir marka ürün yelpazesi barındırmaktadır. Sivas'ta kent ekonomisine kazandırma potansiyeline sahip 
tarih ve kültür değerleri, maden ve jeotermal kaynakları, tabiat varlıkları, dağları, yaylaları, akarsuları ve gölleri ile doğal güzellikleri, bulunmaktadır. Bu kaynaklardan tarih ve kültür değerleri, jeotermal, tabiat varlıkları turizmin geliştirilmesinde, maden ve jeotermal kaynakları ile güneş, rüzgâr enerji potansiyeli ekonominin ve istihdamın geliştirilmesinde ve dışarıya göçün engellenmesinde, su kaynakları ve akarsuları enerji üretiminde, içme, kullanma ve sulama suyu temininde, iklimi, dağları, yaylaları ve ovaları tarım ve hayvancılığın geliştirilmesinde, tarih ve kültür birikimi ile maden ve jeotermal kaynakları ise bilim, sanayi ve teknoloji merkezi yapılmasında stratejik değerlere dönüştürülebilir (Ayaz, 2016: 43).

Görüleceği üzere Sivas İl'i son dönemlerde genç işsizliği ve buna bağlı olarak artan göç oranlarıyla dikkat çekmektedir. Şüphesiz ki etkin ve verimli bir biçimde geliştirilecek olan markalaşma çalışmaları kentin ekonomisine katkı sunacak ve özellikle turizmin geliştirilmesi yoluyla istihdama katkı sağlayacaktır.

\subsection{Sivas'ta Markalaşma Süreci}

Son dönemlerde dünya genelinde hız kazanan markalaşma sürecine Sivas Kenti de kaçınılmaz olarak dahil olmuştur. Ekonomik ve sosyal dönüşümün hızlandığı küreselleşme sürecinde Sivas Kenti de kendisini ulusal ve küresel platformlarda daha iyi tanıtarak yatırımcı ve turist çekmeye çalışarak ekonomisine katk1 sunmak istemektedir. 1970 sonrası sanayisizleşme sürecine girilmesiyle birlikte Sivas Kentinde de devletin sanayi yatırımları azalmıştır. Kent ekonomisinde sanayiinin payı azalarak hizmetler sektörünün payı artmaya başlamıştır. Sivas kenti de dünyadaki gelişmeler paralelinde ekonomisini güçlendirebilmek için markalaşma çalışmalarına başlamıştır.

Tüm dünyada ve Türkiye'de olduğu gibi son dönemlerde kentin tanıtımı için Sivas'ta da markalaşma çalışmalarına ağırlık verilmeye başlanmıştır. Gerek merkezi yönetim gerekse yerel yönetim tarafından çeşitli politikalar oluşturulmaya ve uygulanmaya başlamıştır. Ancak yapılan markalaşma çalışmaları incelendiğinde bu çalışmaların daha çok "turizm” ağırlıklı olarak yapıldığı görülmektedir. Kentlerin yerel özelliklerini ön plana çıkararak markalaşmasını sağlayacak olan en önemli çalışma "Türkiye Turizm Stratejisi 2023 Eylem Planı" dır. 2007 tarihinde Kültür ve Turizm Bakanlığı tarafından geliştirilen "Türkiye Turizm Stratejisi 2023 Eylem Planı"nda Amasya, Adiyaman, Trabzon, Bursa, Edirne, Gaziantep, Hatay, Konya, Kütahya, Manisa, Nevşehir, Kars, Mardin, Sivas ve Şanlıurfa kentlerini marka kent haline getirme hedefi konmuştur. Bu illerden birisi olan Sivas'ta da bu tarihten itibaren markalaşma çalışmalarına hız verilmiştir. Sivas Valiliği, Orta Anadolu Kalkınma Ajansı (ORAN), Sivas Belediyesi, Sivas Cumhuriyet Üniversitesi ve Sivas Ticaret ve Sanayi Odasının destekleri ile ilde 2008 yılında Marka Kent çalışmaları başlamıştır. 2013 tarihinde Sivas Marka Kent Strateji Üst Kurulu ve Marka Kent Yürütme Kurulu oluşturularak markalaşma çalışmalarına hız verilmiştir.

Sivas'ın ulusal ve uluslararası mecralarda tanıtımı amacıyla www.sivas.com.tr adında bir internet sitesi kurulmuştur. Sivas'a ve turizm aktivitelerine özel hazırlanan bu sitede, Sivas'a ait tüm tanıtım materyalleri, haber bültenleri, afişleri, posterleri yayımlanmaktadır. Ayrıca Sivas Tatil Planlama Sitesi adı altında kurulan sivas.markakent.com sitesi de Sivas'a gelecek olan turistlerin tatillerini planlamaları amaciyla hayata geçirilmiştir. Kentin tarihi, kültürel ve turistik değerlerini ön plana çıkarmak, kenti ziyaret eden turistlere planlı bir gezi programı oluşturmak için çalışmalarını sürdüren Marka Kent Sivas Yürütme Kurulu bu doğrultuda turizm paketleri oluşturmuştur (http://www.sivasirade.com/haber/-2167.html). Yine kentin tanıtımına katkı sunmak amacıyla ORAN Kalkınma Ajansı Sivas İl Turizm Logosu tasarlatılmıştır.

Markalaşma çalışmalarının etkin ve verimli sonuca ulaşması için gerekli en önemli hususlardan biri de kurumlar arası koordineli çalışmalardır. Kurumlar arasında işbirliği ve koordinasyon oluşturulması amaca ulaşılabilirliği daha da hızlandıracaktır. Sivas'ta yapılan markalaşma çalışmalarında kurumlar arası bu işbirliğine oldukça önem verilmektedir. Bu amaçla "Sivas İl Kültür ve Turizm Müdürlügü" şehrin potansiyelini belirlemeye yönelik çeşitli çalışmalar yaparak bunları ilgili kurumlara sunmaktadır. Sivas İl kültür ve Turizm Müdürlüğü tarafından 2016 tarihinde hazırlanan "Sivas İl Turizm Master Planı" ve "Sivas 
İli Turizm Potansiyeli ve Turizm Alanı Yatırım Önerileri” çalışmaları, şehrin potansiyeli ortaya koyması ve belirlenecek olan politikalar açısından yol gösterici öneme sahiptir.

Marka Kent Sivas Yürütme Kurulu tarafından Sivas şehrinin ön plana çıkan sembollerinden olarak ifade edilen "gardaşlık ruhu", "4 Eylül Sivas Kongresi", "el sanatları", "gastronomi kültürü" ön plana çıkarılmaya çalışılarak Sivas'ın marka değerine katkı sunulmak istenmektedir. Böylelikle şehri ulusal ve uluslararası platformlarda cazibe merkezi haline getirmek ve Sivas'a yatırım çekebilmek, Sivaslı esnafın çeşitli alanlarda markalaşmasını sağlayarak aktif marka ürün sayısını artırmak ve İç Anadolu Bölgesi’nde bir yatırım üssü haline getirmek amaçlanmaktadır.

'Sivas Turizmini Markalaştırma Projesi' adı altında oluşturulan proje ile ise Sivas'taki gezi alanları paket programlar ve turizm acenteleri aracılığı ile pazarlanarak şehre yerli ve yabancı turist çekilmeye çalışılmaktadır. Bu kapsamda Sivas'ın önemli kültürel değerleri olan markalaştırılmaya çalışılan destinasyon alanlarına 2'şer ya da 3'er günlük paket proğramlar düzenlenmektedir. Ayrıca Sivas Valiliği İl Kültür ve Turizm Müdürlüğü tarafından 2013 yılında hazırlanan "Sivas'ta Kültür ve Turizmi Geliştirme Strateji Planı" çerçevesinde ilin markalaşmasına yönelik bir takım stratejiler belirlenmiştir. Bu stratejiler; Sivas'a özgü kültürel ve doğal ürünlerin markalaştırılarak turizme kazandırılması ve sağlı, inanç ve doğa turizminin canlandırılmasıdır (Sivas’ta Kültür ve Turizmi Geliştirme Strateji Planı, 2013).

Genel olarak Sivas'ta markalaşma yolunda geliştirilen çalışmalara bakıldığında şehrin yerel ürünlerinin ülke çapında tanıtımına ve turist çekmeye yönelik projeler geliştirildiği görülmektedir. Bu noktada belirlenen stratejilerin sorunsuz bir şekilde uygulamaya geçirilmesi için yerel birimlere önemli görevler düşmektedir. "Şehre Turist Çekme" ekseninde yapılan markalaşma çalışmalarında önemli nokta; tanıtımların daha çok "günlük turlar" şeklinde olmasıdır. Yerel birimler tarafından çeşitli turizm acenteleriyle yapılan anlaşmalarla paket geziler düzenlenmektedir. Şehrin ülke çapındaki tanıtımına elbette katkı sağlayacak olan bu programların geliştirilmesi gerekmektedir. Sivas’ta markalaşma çalışmalarının bu küçük ölçekten çıkarılıp daha geniş bir ölçekle yapılması kentin tanıtımı açısından gerekli görülmektedir.

Çalışmada öncelikle neo-liberal kentleşme sürecinde sanayisizleşme politikalarının kentler üzerindeki ele alınacak ve ardından metalaştırılan kentlerin ekonomik kalkınmalarını sağlamak için markalaşma çalışmaları incelenecektir. Taşra kentlerindeki markalaşma çalışmaları Sivas örneği üzerinden ele alınarak sonuç kısmında ise sahadan elde edilen veriler ışığında değerlendirme ve önerilerde bulunulacaktır.

\section{ARAŞTIRMANIN AMACI, KAPSAMI, YÖNTEMİ VE BULGULARI}

\section{1. Araştırmanın Amaç ve Kapsamı}

$\mathrm{Bu}$ araştırmanın amac1; Orta Anadolu'da bir taşra kenti olan Sivas'ta yapılan markalaşma çalışmalarını değerlendirmektir. Araştırma, özellikle 1970'li yıllardan sonra hız kazanan kapitalist kentleşme dinamikleri doğrultusunda ortaya çıkan kentlerde sanayii yatırımlarının azalması sonucu kentlerin ekonomik kalkınma sağlamak amaciyla gerçekleştirmeye çalıştı̆̆ markalaşma stratejilerini ele almaya çalışmaktadır. Gerçekten de Sivas kenti son dönemlerde sanayi yatırımlarının azalarak hizmetler sektörünün ön plana çıkmaya başladığı tipik Anadolu kentlerinden biridir. Bu çalışmada Sivas'ta yapılan markalaşma çalışmaları yerel politika yapıcıların değerlendirmeleri doğrultusunda saptanmaya çalış1lacaktır. Elde edilen verilere göre çalışmanın sonuç kısmında çeşitli önerilerde bulunulmuştur. Çalışmada elde edilen verilerin markalaşma çalışmaları açısından kente katkı sağlayacağı beklenmektedir.

\subsection{Araştırmanın Yöntemi ve Örneklemi}


$\mathrm{Bu}$ araştırmada, nitel araştırma yöntemlerinden biri olan görüşme(mülakat) tekniği kullanılarak, Sivas Ill'inin markalaşma süreci ile ilgili olarak 21 kişi ile derinlemesine görüşmeler yapılmıştır. Bu kişilerin seçilme nedeni, kentsel markanın oluşturulma sürecinde kenti tanıyan ve markalaşma sürecinde çalışmalarda bulunan kişilerin düşünceleri üzerinden bir değerlendirme yapmak ve bu doğrultuda öneriler sunabilmektir.

Bu kişiler, Sivas'ın markalaşma çalışmalarında proje geliştirme ve uygulama sahasında bizzat yer almış olan İl Kültür ve Turizm Müdürlüğü çalışanları, Valilik çalışanları, şehir plancısı, belediye başkan yardımcısı ve akademisyenlerden oluşmaktadır. Bu kişilerden şehrin markalaşma çalışmalarının ulaştığ 1 düzey hakkında bilgiler alınmıştır. 7 kişiden oluşan bu yönetici grup haricinde şehir markasının algılanış1 ile şehrin konumlandırılmasının kent ekonomisine katkısının değerlendirilmesi açısından ise 14 kent sakini vatandaş ile görüşmeler yapılmıştır.

Araştırma kapsamında, Sivas’ta yürütülen marka kent çalışmalarının çeşitli boyutlardaki etkilerine ilişkin detaylı bilgilere ulaşmak amacıyla yarı yapılandırılmış sorular aracılığıyla derinlemesine görüşmeler yapılmıştır. Bu görüşmelerde yoğunluklu olarak markalaşma çalışmalarının kentsel ekonomik gelişimle olan ilişkisi üzerine odaklanılmıştır.

$\mathrm{Bu}$ araştırmada Sivas İl’inde markalaşma çalışmaları kapsamındaki kişi veya kurumlara kartopu yöntemiyle ulaşılarak derinlemesine görüşmeler gerçekleştirilmiştir. Araştırmada görüşmeye katılan kişilerin görüşleri kurumları ve kimlikleri belirtilmeden kodlama yoluyla çalışmaya aktarılacaktır.

\subsection{Araştırmanın Bulguları}

"Sivas’ta yapılan markalaşma çalışmaları ne düzeydedir? Bu güne kadar hangi çalışmalar yapıldı? Çalışmaların içerikleri nelerdir?" sorusuna katılımcıların verdikleri cevapları genel olarak toparlarsak: "Sivas'ta markalaşma çalışmaları 2005 yılından itibaren hız kazanmaya başlamıştır. "Anadolu'nun parlayan yıldızı Sivas olacak” sloganıyla şehrin özgünlükleri dünya çapında tanıtılmaya çalışılacaktır. Bu konuda Sivas Valiliği, Sivas Belediyesi, İl Turizm ve Kültür Müdürlüğü ve Orta Anadolu Kalkınma Ajansı (ORAN) gereken adımları atmıştır. Bu kurumlar arasında koordineli bir çalışma yürütülmektedir. 2007 tarihinde Kültür ve Turizm Bakanlığı tarafından geliştirilen "Türkiye Turizm Stratejisi 2023 Eylem Planı"nda Sivas kentinin de içinde bulunduğu bazı kentler için marka kent hedefi konmuştur. Bu plan sonrasında çalışmalar hız kazanmıştır. Öncelikli olarak şehrin marka unsuru olabilecek ve Sivas'ın tanıtımına fayda sağlayacak olan yerel ürünleri belirlenmiştir. Bunlar için çeşitli stratejik planlar oluşturularak yerel idare birimlerine sunulmuştur. Ayrıca üniversite ve sivil toplum kuruluşları gibi paydaşlardan fikirler alınarak değerlendirme sunmaları istenmiştir. Sivas'1 marka kent haline getirebilecek yerel ürünler bakımından oldukça zengindir. Bu güne kadar Sivas'a özgü kadar birçok ürün tescillenmiştir ve diğerlerinin de tescillenme çalışmaları devam etmektedir.

Son y1llarda özellikle kentin turizm potansiyelini artırmak için Sivas Valiliği ve Sivas Belediyesi işbirliğiyle çok sayıda proje hayata geçirilmeye başlanmıştır. Örnek vermek gerekirse; 2020 yılında Sıcak Çermik'in turizme kazandırılması için yapılan Altın kale projesi sayesinde gerek yurt içinden gerekse yurt dışından çok sayıda turistin Sivas'a gelmesi beklenmektedir. Yine tarihi Sivas kalesinde faaliyete geçirilecek olan projenin Sivas'ın tanıtıma fayda sağlayacağı düşünülmektedir. Aynı şekilde aç1lış1 2020'de yapılan Abdulhamit Han Müzesi de Sivas'ın ismini duyurmasını sağlayacaktır.

Kente turist çekme yoluyla kent ekonomisini canlandırmayı amaçlayan bu turistik faaliyetler dışında Sivas'ın yerel ürünleri için coğrafi işaretler alınmıştır. Sivas köftesi, Sivas bıçağı, Sivas katmeri, Sivas taklacı güvercin gibi Sivas'ın kimliğini yansıtan ürünlerde ekonomiye katkı sunacaktır”.

“Marka kent haline gelmenin Sivas ekonomisine nasıl katkıda bulunduğunu/bulunacă̆ını düşünüyorsunuz?” sorusuna ise, "Diğer ülkelerde ve Türkiye'de markalaşma çalışmalarının temel hedefi 
genel olarak ülkelerin ya da kentlerin tanınırlığını artırmak ve bu sayede kente yatırımcı ve turist çekmektir. Gerçekten de marka kent olmayı başarabilmiş kentler ekonomik açıdan oldukça gelişme göstermiş̧lerdir. Bu noktada Sivas şehrinde markalaşma çalışmaları sayesinde yurt dışında ve yurt içinde daha çok tanıtacak ve daha çok turist çekecektir. Markalaşma çalışmaları neticesinde Sivas'ta yabancı yatırımcı sayısı artmaya başlamıştır. Bu yatırımcılar ya doğrudan yatırım yapmakta ya da Sivaslı firmalarla çeşitli ortaklıklar kurmaktadır. Yine son dönemlerde hammaddesi Sivas'tan sağlanan birçok ürün Sivas'ta üretilip yurtdışına ihraç edilmektedir. Kozmetik, demir-çelik aksanlı hastane ekipmanları, iklimlendirme ürünleri ve tekstil gibi alanlarda ihracat yapan firma sayısı artmıştır. İstatistik verileri de özellikle 2006 sonrası ihracatın artıı̆ını doğrulamaktadır. Bu artış özellikle ihracat yapılan ülke sayısındaki artış şeklinde olmaktadır. Bu artışlar Sivas'ın uluslararası bilinirliğinin arttı̆̆ını göstermektedir.

Markalaşma çalışmalarının kent ekonomisine bir başka faydası ise turizme kazandırılan yerler açısından turizm gelirlerinin artması olmuştur. Bu durum şehir esnafının gelirinin artması demektir. Ayrıca tarihi ve turistik yerlerde kurulan sosyal donatı alanları istihdam açısından ve Sivas'ın en büyük problemlerinden biri olan işsizliği azaltmaya katkı sağlayacaktır.

Şehrin tanınırlığının artmasının kent ekonomisi üzerinde bir başka faydası Cumhuriyet Üniversitesinin öğrenciler tarafından daha çok tercih edilmeye başlanmasıdır. Daha önceki dönemlerde öğrenci profili daha çok yakın kentlerle sınırlı iken şu anda Türkiye'nin ve hatta dünyanın birçok yerinden öğrenci tarafından tercih edilir hale gelmiştir".

Aşağıdaki sorular ise kent sakini olan 14 kişiye sorulmuştur. Soru yöneltildikten sonra görüşmecilere marka kent hakkında kısaca bilgi verilmiş olup daha sonra soruyu yanıtlamaları istenmiştir.

Sizce Sivas'ın marka bir kent olabilme potansiyeli var mı? Varsa hangi değerleriyle marka kent olabilir? Ve Sivas'ın yeterince tanıtıldığını düşünüyor musunuz? sorusunu genel olarak görüşmecilerin hemen tamamına yakını Sivas'ın marka kent olma potansiyelinin bulunduğu şeklinde cevaplamışlardır.

"Sivas tabi marka olabilir niye olmasın. Sivas'taki tarih nerde var. Burası Bizans'tan Selçukludan kalma şehir. Atalarımız ne eserler yapmış Sivas'a. Divriği'deki Ulucami’nin eşi benzeri yok dünyada. Çifte minare gene öyle. Ama kaç yabancı turist geliyor bunları görmeye. Bilmiyorlar ki gelsinler. Bu eserler başka yerde olsa nasıl turist gelirdi buralara“.

(Görüşmeci 1, erkek, 69 yaşında, Emekli, memleket: Sivas)

“Sivas'ta ne cevherler var doğru düzgün tanitılsa. Bir Âşıl Veysel’imiz var mesela çok büyük ozan. Ama Sivas yeterince sahip çıkmıyor ona. Daha doğru düzgün bir caddeye ya da başka bir yere ismi bile verilmemiş. Sivas kendi sahip çıkmazsa bu değerlere el ne bilsin. Önce biz sahip çıkacă̆ız, başımızdakiler sahip çıkacak”.

(Görüşmeci 2, erkek, 52 yaşında, emekli, memleket: Sivas).

“Ben 65 yaşındayım daha Sivas'ta yabancı turist ya 1 tane gördüm ya taş çatlasın 2 tane. Yabancı turist bilmiyor bizim buralarl. Tanımiyorlar. Yerli turist dediğin de Istanbul'dan gelenler zaten. Buranın insanı hep İstanbul'a göç etmiş. Yazın memleketim diye geliyorlar buraya. Almancı da çoktur Sivas 'ta. Yazın İstanbullularla Almancılar geliyor da esnafin yüzü gülüyor”.

(Görüşmeci 3, erkek, 65 yaşında, emekli, memleket: Sivas).

"Kangal'daki balıklı kaplıca ve merkezde bulunan sicak ve soğuk çermik çok iyi bir turizm potansiyeli oluşturabilir mesela. Ama yıllarca çok bakımsız bırakıldı çermikler (kaplıcalar). Çermiklere insanlar taa yurtdışından geliyor ama bakımsız. Birçok kent termal turizm üzerinden kendini çok geliştiriyor. Sivas'ta da bu yapılabilir mesela”. 
(Görüşmeci 4, kadın, 34 yaşında, esnaf, memleket: Sivas).

“Sivas pekâlâ Marka bir şehir olabilir. Biz Ankara'lıyız ama seviyoruz Sivas'ı. İnsanı çok iyi, sevecen, cana yakın. Sakin, temiz ve yaşanılabilir bir şehir. Trafik yok, hava kirliliği yok, suları içilebilir. Trafikte stres olmuyorsunuz en azından. Bunlar bile yaşam kalitenizi artırabilir şeyler. Buraya gelmeden önce önyargılarımı vardı ama burayı görünce gerçekten yıkıldı o önyargılarımız. Açıkçası tavsiye ederim Sivas'ı başkalarına da”.

(Görüşmeci 5, kadın, 30 yaşında, sağlık çalışanı, memleket: Ankara).

“Bilmiyorum belki olabilir. Yani çok fazla bir özelliği yok Sivas’ın bence. Biz ögrenciyiz burada. Ben Sakarya'dan arkadaşım da Eskişehir'den geldik. Ama ne bileyim okul haricinde yapabilecek çok şey yok burada. Hafta sonları çarşlya çıkıyoruz ya da A.V.M var bir tek ögrencinin gidebileceği. Gençlere yönelik mekânlar fazla yok.

(Görüşmeci 6, kadın, 20 yaşında, öğrenci, memleket: Sakarya).

"Sivas son yıllarda ekonomik açıdan bir gerileme içinde maalesef. Devlet sanayii yatırımı yapmiyor artık. Özel sektörde tercih etmiyor. Sivas'ta istihdam olanăğ pek kalmadı, O yüzden Sivas çok göç veren bir şehir. Evet, markalaşma çalışmaları işe yarayabilir. En azından Daha fazla turist alırız da ekonomimiz canlanır. Duyduğumuz bir takım projeler var. Bunlar başarılı bir şekilde uygulanırda hem esnafimızın da yüzü güler. Çünkü işsizlik çok fazla ve gençler iş bulamayınca esnaflık yapmak zorunda kalıyor. Ama çoğu da iş yapamıyor ve kapatıp gidiyor. Sivas'a turist çekmek lazım, giden insanını geri getirmek lazım. Istihdam artsın istiyoruz Sivaslılar olarak".

(Görüşmeci 7, erkek, 48 yaşında, esnaf, memleket: Sivas).

Yine aşağıdaki iki soru kent sakini olan aynı 14 kişiye sorulmuştur.

“Sivas'ın ekonomik gelişmişliğini nasıl değerlendiriyorsunuz? Marka kent olma çalışmalarının Sivas ekonomisine katkıda bulunduğunu/bulunacağını düşünüyor musunuz?” şeklinde yöneltilen soruda ise katılımcıların geneli Sivas'1 gelişmemiş daha doğrusu geri kalmış ya da gerilemiş bir şehir olarak nitelendirmektedir. Bazı katılımcılar ise Sivas'ın son zamanlarda gelişmeye başladığını ifade etmişlerdir. Katılımcıların Sivas'a ilişkin algılarında en büyük sorun olarak gördükleri konu işsizlik ve göçtür. Özellikle son zamanlarda ilçe köylerinin tamamen boşaldığını, gençlerin Sivas'ta iş imkânı bulamadığı için İstanbul'a göç ettiğini ifade etmektedirler. Markalaşma çalışmalarının başarılı olması durumunda Sivas'ın daha iyi tanınacağını ve daha fazla turist çekeceğine inandıklarını belirtmişlerdir. İstanbul'a ya da diğer büyük şehirlere göç etmiş iş adamlarının yatırımlarını Sivas'a çekme konusunda yerel yöneticilerin çalışmalarda bulunması gerektiği vurgulanmıştır.

“Kentsel markalaşma konusunda yerel politika yapıcılara önerileriniz var mıdır?" sorusuna verilen cevaplar şu şekilde kategorize edilebilir:

Sivas'ın tarihi eserleri daha iyi tanıtılmalı. Sivas'ta bulunan tarihi camii, medrese, külliye, han, hamam gibi yapılar turizme kazandırılmalı.

Sivas'ın özgün ürünleri olan madımak, aluç, kuşburnu gibi endemik bitkilerin pazarlaması yapılmalı.

Sivas'ın sembollerinden bir olan Kangal köpeğine gereken önem verilmeli ve dünyaya tanıtılmalı.

Sivas'ın halk ozanlarına sahip çıkılmalı, onları tanıtacak etkinlikler düzenlenmeli.

Gençlere yönelik sosyal alanların sayısı artırılmalı.

Ülke kamuoyunda Sivas hakkında daha olumlu bir imaj oluşturulmalı. 
Kırdan kente göçü önlemek için tarıma destek verilmeli.

Kaplıcalara gereken önem verilmeli ve termal kaynaklar kent ekonomisine kazandırılmalı.

Sivas Yıldız Dağı kış turizmi açısından kente turist çekecek bir potansiyele sahiptir. Bu merkezin turistik altyapısı güçlendirilerek tanıtım çalışmalarına ağırlık verilmelidir.

\section{SONUÇ VE ÖNERILER}

1970 sonrası dönemde yaşanan ekonomik dönüşümün ekonomik, sosyal ve politik sonuçları olduğu kadar mekânsal sonuçları da oldukça önemli olmuştur. Neo-liberalizm olarak adlandırılan dönüşüm süreci, ülkeleri olduğu kadar kentleri de derinden etkilemiştir. Neo-liberal politikaların bir sonucu olarak artık kentlerde sanayinin göreli önemi azalmakta ve hizmetler sektörünün önemi artmaktadır. Bu gelişmelerin mekânsal örgütlenmeye ve kentlere yönelik oldukça önemli sonuçları ortaya çıkmaktadır. Bu süreçten metropol kentleri kadar etkilenen taşra kentleri de yerel özgünlüklerini ve yerel kaynaklarını kullanarak yerel kalkınmalarını gerçekleştirmeye çalışmaktadırlar. Yeterli sanayi yatırımı alamayan taşra kentleri, yerel özgünlüklerin "markalaştırılması" yoluyla kentlerine daha çok turist ve yatırımcı çekmenin yollarını aramaktadırlar.

Sözü edilen bu kentlerden biri olan Sivas'ta da benzer bir süreç yaşanmaktadır. Özellikle 1980 sonrası dönemde neo-liberal politikalar sonucu devlet yatırımlarının azalması kenti sanayi yatırımlarının azalmasıyla karşı karşıya bırakmıştır. Bu durumun etkisiyle şehirde işsizlik ve buna bağlı olarak da göç hızlanmıştır. Bu noktada birçok kentte olduğu gibi Sivas'ta da markalaşma çalışmaları ön plana çıkarak kent ekonomisi geliştirilmeye çalışılmaktadır. Kente küresel ve ulusal düzeyde yatırımcı ve turist çekebilmek amacıyla çeşitli politikalar oluşturulmaya başlanmıştır. Bu amaçla 2007 yılında Kültür ve Turizm Bakanlığı tarafından markalaştırılması gereken 15 il kapsamına alınan Sivas kentinde bu tarihten sonra markalaşma çalışmaları hız kazanmıştır. Kente daha fazla turist ve yatırımcı çekebilmek amacıyla birçok tanıtım çalışması yapılmaktadır. Bu amaçla kentin tarihi, turistik ve doğal özellikleri markalaşma çalışmaları kapsamına alınmaktadır. Kentin ulusal ve uluslararası platformlarda tanınırlı̆̆ının ve bilinirliliğinin artırılması amacıyla yerel aktörler arasında koordineli olarak sürdürülen bir takım çalışmalar devam etmektedir.

Çalışmanın teorik ve saha kısmı uygulamalarından elde edilen sonuçlara göre Sivas marka olabilme potansiyeline sahip bir kenttir. Köklü geçmişinden kaynaklanan tarihi eserleri, yeraltı ve yer üstü zenginlikleri, doğal güzellikleri, endemik bitki ve hayvan çeşitliliği, üniversitesi vb. gibi kaynaklar bakımından oldukça zengindir. Bu kaynakların etkin ve verimli bir biçimde kullanılması kent ekonomisini geliştirecektir. Yapılan görüşmelerden elde edilen verilere göre Sivas'ta son dönemde hız kazanan markalaşma çalışmaları sayesinde yerli ve yabancı yatırımcılar kenti tercih etmeye başlamışlardır. Ayrıca kültür ve turizm odaklı markalaşma çalışmaları ise kentin turizm gelirlerini artırmaya katkı sağlamıştır.

Sahadan elde edilen bulgular Sivas halkının kent markalaşması fikrine olumlu yaklaştığını göstermektedir. Yerel birimler tarafından markalaşma süreci iyi yönetilirse kentte istihdamın artacağı düşünülmektedir. Bu noktada merkezi yönetimin kaynak aktarması ve yerel birimlerin de etkin politikalar geliştirmeleri gerektiği düşünülmektedir.

Bu sonuçlara göre Sivas’ta gerçekleştirilmeye çalışılan markalaşma sürecine ilişkin olarak şu öneriler ileri sürülebilir:

- Verimli bir markalaşma çalışması için öncelikle doğru bir durum tespiti yapılmalıdır. Eldeki kaynaklar akılcı bir biçimde ele alınmalı ve bu süreci doğru konumlandırma, uygun strateji geliştirme, istikrarlı ve sürdürülebilir politikalar ve yatırım sağlama süreçleri izlemelidir. 
- Marka kent olabilmek için kenti tanıtan çeşitli marka, slogan ve semboller ön plana çıkarılmalıdır. Bu noktada Sivas köftesi, madımak, aluç, Kangal köpeği, Kangal koyunu gibi özgün kaynaklara yönelerek kentin tanıtımına katkı sağlanabilir.

- Markalaşma çalışmalarında tüm paydaşlar katkı sunmalıdırlar. Yerel yönetim birimleri, Sivil toplum örgütleri, kalkınma ajansları, özel sektör kuruluşları ve halkın görüşleri doğrultusunda ortak stratejik planlamalar yapılmalıdır.

- Marka oluşturmak isteyen yerel yönetimler kentin konumlandırılması, kente dair kimlik ve imaj oluşturulması noktasında profesyonel ajanslardan destek almalıdırlar. Bu ajanslar kentin tarihini, kültürünü ve diğer potansiyellerini yakından tanıyan nitelikli ajanslar olmalıdırlar. Örneğin ajans tarafından geliştirilmiş kenti iyi yansıtan bir kent logosu oldukça yararlı olacaktır.

- Kentin rekabet edilebilirliğini ve çekim gücünü artırmak için yatırımcılara için uygun yatırım imkânları sunulmalıdır. Üretim, pazarlama ve ihracat aşamalarında gerekli finans desteği sağlanmalıdır.

- Sivas'ın en önemli problemlerin biri olan kırsaldan göçü önlemek amacıyla tarımsal politikalar geliştirilmelidir. Sivas tarım ve hayvancılık açısından oldukça elverişli bir yapıya sahiptir. Çiftçilere gereken destek sağlanarak tarım ve hayvancılığın yaygınlaştırılması sağlanmalıdır. Son dönemde uygulamaya geçirilen Kangal Koyunu yetiştirme projesine verilen desteğin kapsamı diğer tarımsal ve hayvansal ürünleri de içerecek biçimde genişletilmelidir.

- Üniversite öğrencilerine ve gençlere yönelik olarak sosyal donatı alanlarının sayısı artırılmalıdır. Araştırmadan elde edilen bulgulardan birisi de üniversite öğrencilerinin vakit geçirebileceği sosyalleşme alanlarının yetersiz oluşudur. Sanat, spor, kültür vb. alanlarda etkinlik sayıları ve kaliteleri artırılmalidir.

- Sivas'ın yerel ve küresel ağlarda tanınırlığını artırmak amacıyla web ortamına önem vermelidir. Etkileyici ve akılda kalıcı bir logo ön plana çıkarılmalı ve çeşitli sosyal platformlar üzerinden kentin tanitımı yapilmalıdır.

Kısaca toparlamak gerekirse küreselleşme döneminin ortaya çıkardığ "markalaşma üzerinden gelişme stratejileri" kaçınılmaz olarak tüm kentleri içine almaya başlamaktadır. Sivas kenti de bu sürece eklemlenmek için son dönemlerde markalaşma çalışmalarına hız vererek kente yatırımcı ve turist çekmeye çalışarak kentsel ekonomiyi geliştirmeye çalışmaktadır. Azalan sanayi sektörünün yerini hizmetler ve turizm sektörleriyle doldurmaya çalışan kent yönetimleri markalaşma yoluyla kentlerine yatırımcı ve turist çekmenin yolunu aramaktadır. Bu gelişmeler doğrultusunda Sivas kenti de markalaşma stratejileri ile kente istihdam kazandırma amacıyla kentsel politikalarını dönüştürmeye başlamıştır.

Çıkar Çatışması: Yazarlar herhangi bir çıkar çatışması bulunmamaktadır.

Etik Kurul İzni: Bu çalışma için etik kurul iznine gerek yoktur 


\section{KAYNAKÇA}

AYAZ, M.Emrah, (2016), "Sivas Şehir Kimliği ve Sürdürülebilir Kalkınma Öneriler”, Maden Tetkik ve Arama Genel Müdürlüğü Doğal Kaynaklar ve Ekonomi Bülteni, S. 3, Ankara, s. 43-64.

ÇALAPKULU, Çiğdem, Kübra KIZILDAĞ, (2021), “Küresel Mega Marka Şehir: Dubai’nin Markalaşma Süreci ve Marka Algısına Yönelik Araştırma", The Journal of Social Science, Y1l. 5, C. 5, S. 9, ss. 210-225.

DUMENIL, Gerard, Dominique Levy, (2005), “The Neoliberal Revolution”, Neoliberalism A Critical Reader, (ed. Alfredo Saad-Filho ve Deborah Johnston), London: Pluto Press, ss. 9-20.

DÜNDAR, Şebnem Gökçen, (2010), “Unvan Peşindeki Kentler: "Mega” Projeler ve "Mega Etkinlikler" Üzerinden Bir Bakış”, Mimarlık Dergisi, Sayı: 353, ss. 53-58.

ERSOY, Melih, Tarık, Şengül, (1998), “Küreselleşme ve Yarışan Yerellikler”, 1997 Sanayi Kongresi, Bildiriler Kitabı, TMMOB Makine Mühendisleri Odası, Yayın No: 209 Ankara: ss.135139.

ERSOY, Melih, (2001), “Sanayisizleşme Süreci ve Kentler”, Praksis Dergisi, Sayı: 2, ss.32-52.

GÖRGÜLÜ, Yusuf, (2020), "Kent Markalama Sürecinde Yönetimsel İletişim Stratejileri, İzmir Büyükşehir Belediyesi örneği, Journal of Social and Humanities Sciences Research, S. 7(51), ss.715726.

HARVEY, David, (2010), Postmodernliğin Durumu: Külttürel Değişimin Kökenleri, (çev. Sungur Savran), İstanbul: Metis Yayınları.

HOVARD, M.C, J.E. King, (2008), The Rise of Neoliberalism in Advanced Capitalist Economies, London: Palgrave Macmillan.

İNCE, Esma İclal DİNÇER, (2017), "Marka Kent Bağlamında Kent Kimliğinin Konut Projelerinin Pazarlanmasında Kullanılması: İstanbul Örneği”, Megaron Dergisi, Cilt: 12, Sayı: 4, ss. 635646.

JESSOP, Bob, (2005), Hegemonya, Post Fordizm ve Küreselleşme Ekseninde Kapitalist Devlet, (der. Betül Yarar ve Alev Özkazanç), İstanbul: İletişim Yayınları.

KAYPAK, Şafak, (2013), "Küreselleşme Sürecinde Kentlerin Markalaşması ve "Marka Kentler”, C.Ü. İktisadi ve İdari Bilimler Dergisi, Cilt: 14, Say1: 1, ss.335-355.

KAZGAN, Gülten, (2000), İktisadi Düşünce veya Politik İktisadın Evrimi, 9. Baskı, İstanbul: Remzi Kitabevi.

KOTLER, P., Haider, D. and Rein, I. (1993), Marketing Places: Attracting Investment, Industry and Tourism to Cities, States, and Nations, Maxwell Macmillan Int, New York.

OĞAN, Okan, YASAK Üzeyir, (2020), "Küreselleşme Bağlamında Mekânsal Kent Kimliği Ve Markalaşmanın Kent Turizmine Etkisi”, Türk Coğrafya Dergisi, S. 74, ss. 97-105.

ORAN (Orta Anadolu Kalkınma Ajans1), TR72 Bölgesi 2014-2023 Mevcut Durum Analizi.

ÖZBEK, Nadir, (2007), "Refah Devletinin Krizi, Yeni Sosyal Politika Önerileri ve 'Temel Gelir' Üzerine Düşünceler." Mesele Kitap Dergisi, No: 11, ss. 43-46. 
ÖZDEMİR, Süleyman, (2007), “Küreselleşme ve Refah Devletleri Üzerindeki Etkileri”, Sosyal Siyaset Konferansları Dergisi, Cilt: 1, S: 57, ss. 55-86.

ÖZERK, Gaye B., Berrin Akgün Yüksekli, (2011), “Küresel Kent, Kentsel Markalaşma ve Yok-Mekân İlişkileri”, İdeal Kent Dergisi, Sayı:3, ss. 82-93.

PENPECİOĞLU, Mehmet, (2013), "Büyük Ölçekli Kentsel Projeler, Mekânın Üretimi ve Neo-Liberal Hegemonya: İzmir Örneğinde Karşılaştırmalı Bir Araştırma”, Megaron, Cilt: 8, Sayı: 2, ss. 97-114.

ROSANVALLON, Pierre, (2000), The New Social Question- Rethinking the Welfare State, New Jersey: Princeton University Press.

TÜRKIYE TURIZM STRATEJISİ 2023 EYLEM PLANI, (2007), T.C. Kültür ve Turizm Bakanlığı, Ankara.

SERT, Emre, vd. (2005), "Küreselleşme Sürecinde Değişen Kent Kavramı; Mekân ve Politikleşme Üzerine Bir Okuma Çalışması", Planlama Dergisi, Sayı: 2, ss. 101-111.

STEGER, Manfred B, Ravi K. Roy, (2010), Neoliberalism: A Very Short Introduction, New York:

Oxford University Press.

ŞENGÜL, Tarık, (2001), "Sınıf Mücadelesi ve Kent Mekânı”, Praksis Dergisi, Say1: 2, ss. 9-31.

ŞENGÜL, Tarık, (2009), Kentsel Çelişki ve Siyaset, İstanbul: İmge Yayınevi.

TEK, Murat, (2009), “Kamu Yatırımlarında Turizmin Yeri, Türkiye Turizm Stratejisi 2023'de Marka Kentler Projesi: Eleştirel Bir Değerlendirme", Anatolia: Turizm Araştırmaları Dergisi, Cilt 20, Say1 2, ss. 169-184.

UĞURLU, Örgen, (2013), "Neo-liberal Politikalar Ekseninde Türkiye'de Kentsel Mekânın Yeniden Üretimi”, Türk Tabipleri Birliği Mesleki Sağlık ve Güvenlik Dergisi, Ocak Şubat Mart, ss. 2-12.

ZEREN, Halim Emre, (2011), Marka Kent Oluşturma Bağlamında Stratejik Kent Yönetimi: Karaman Kenti İçin Bir Model Önerisi, İnönü Üniversitesi Sosyal Bilimler Enstitüsü Yayımlanmamış Doktora Tezi.

https://www.tuik.gov.tr/Bulten/Index?p=Adrese-Dayal1-Nüfus-Kay1t-Sistemi-Sonuçlar1-2020

http://www.sivasirade.com/haber/-2167.html "Marka Kent Sivas", (Erişim Tarihi: 12.01.2020). 